Article

\title{
Evaluation of Commercial Humic Substances and Other Organic Amendments for the Immobilization of Copper Through 13C CPMAS NMR, FT-IR, and DSC Analyses
}

\author{
Begoña Mayans ${ }^{1} @$, Javier Pérez-Esteban ${ }^{1, *} \mathbb{0}$, Consuelo Escolástico ${ }^{1}$, Enrique Eymar ${ }^{2}$ and \\ Alberto Masaguer ${ }^{3}$ \\ 1 Department of Organic and Bio-Organic Chemistry, Faculty of Sciences, Universidad Nacional de Educación \\ a Distancia, Paseo de Senda del Rey 9, 28040 Madrid, Spain; bego.mayans@gmail.com (B.M.); \\ cescolastico@ccia.uned.es (C.E.) \\ 2 Department of Agricultural Chemistry and Food Sciences, Faculty of Sciences, Universidad Autónoma de \\ Madrid, Calle Francisco Tomás y Valiente 7, 28049 Madrid, Spain; enrique.eymar@uam.es \\ 3 Department of Agrarian Production, Soil Science Unit, Agricultural Engineering School, Universidad \\ Politécnica de Madrid, Avenida Puerta de Hierro 2, 28040 Madrid, Spain; alberto.masaguer@upm.es \\ * Correspondence: jpereze@ccia.uned.es; Tel.: +34-91-398-7321
}

Received: 8 October 2019; Accepted: 14 November 2019; Published: 16 November 2019

check for updates

\begin{abstract}
The application of organic amendments to contaminated agricultural lands can immobilize metals and improve soil conditions. The chemical structures and long-term stability of commercial humic substances and other composted organic amendments (sheep and horse manure, vermicompost, pine bark, and pruning waste) were analyzed using ${ }^{13} \mathrm{C}$ CPMAS NMR, FT-IR, and DSC to evaluate their use in soil remediation. The interactions of humic substances and manure with $\mathrm{Cu}(0$ and $5000 \mathrm{mg} \mathrm{kg}^{-1}$ ) at different $\mathrm{pH}$ (2.5 and 5.0) were studied through a batch adsorption experiment observing the changes in their molecular structure using spectroscopic techniques. Humic substances exhibited high aromaticity and phenolic and carboxylic group content, with great affinity for $\mathrm{Cu}$ complexation. Humic substances and pruning waste were the most stable due to their high recalcitrant organic matter contents, whereas manure was the least stable, given the labile nature of its organic matter content. There were considerable changes in the carboxylic and phenolic groups of humic substances with $\mathrm{pH}$, and also with $\mathrm{Cu}$, albeit in a lesser extent, especially at $\mathrm{pH}$ 5.0, suggesting the great sorption capacity of humic substances and the key role of $\mathrm{pH}$ and these functional groups in metal complexation. Manure did not exhibit such changes. Commercial humic substances could be useful amendments for the remediation of contaminated agricultural soils due to their high sorption capacities and long-term stability.
\end{abstract}

Keywords: nuclear magnetic resonance; copper adsorption; Fourier-transform infrared spectroscopy; differential scanning calorimetry; humic acid; organic matter

\section{Introduction}

The contamination of agricultural soils with heavy metals is a widespread threat for human and animal health. Metal accumulation reduces plant growth and soil microbial activity, affects soil functioning, and may endanger nearby soils and water ecosystems, as well as increasing their transfer to the food chain [1-3]. Copper $(\mathrm{Cu})$ is one such hazardous metal. Despite being an essential micronutrient for all living organisms in natural ecosystems, $\mathrm{Cu}$ is also a toxic pollutant when its concentrations are high. Mean Cu concentration in non-polluted soils is $20-30 \mathrm{mg} \mathrm{kg}^{-1}$; meanwhile, the 
range of concentrations in agricultural soils which could produce phytotoxicity is $60-150 \mathrm{mg} \mathrm{kg}^{-1}$ [4]. In general, $\mathrm{Cu}$ accumulates in the top layers, but its tendency to be adsorbed by soil organic matter, carbonates, and clay minerals may cause it to transfer into deeper layers [4]. Thus, cost-effective and environmentally-friendly remediation techniques should be applied to reduce the toxicity and dispersion of $\mathrm{Cu}$ and other metals, and to limit exposure for humans and other organisms.

The incorporation of organic amendments is a widely-used technique in agricultural lands to increase soil organic matter content, to supply nutrients, and to improve the soil structure and water retention capacity. Organic amendments can not only improve plant growth but can also stabilize $\mathrm{Cu}$ and other metals in soils, reducing their bioavailability and mobility, and therefore, their toxicity and transfer to other ecosystems and into the food chain $[2,3,5,6]$. The organic particles of these amendments contain several functional groups on their surface, such as hydroxyl, phenolic, carboxyl, and sulfhydryl, which control the adsorption and metal complexation mechanisms [3,7].

Humic substances (HS) are among the most studied organic materials that can be used as soil amendments, whose capacity to retain both organic and inorganic pollutants is well known [2,8-10]. However, a great variety of amendments may be derived from organic wastes, such as pine bark, pruning waste, manure, vermicompost, and other types of compost, which could also be used to stabilize metals in contaminated soils $[2,3,5,6]$.

It is of great interest to elucidate at the outset the chemical structure and stability of these organic amendments to predict their behavior and ability to retain or release metals in soils in the long term due to the biodegradation of their organic matter, which can be assessed by Differential Scanning Calorimetry (DSC) thermal analysis by studying the distribution of their labile (i.e., easily thermodegradable) and recalcitrant (hardly thermodegradable) organic matter [11-16]. Additionally, an understanding of the interaction processes between the organic matter of the amendments and metals, and the influence of key factors such as $\mathrm{pH}$, is of primary importance. Spectroscopic techniques, such as Solid-State Cross-Polarization Magic Angle Spinning Carbon-13 Nuclear Magnetic Resonance $\left({ }^{13} \mathrm{C}\right.$ CPMAS NMR) and Fourier Transform Infrared Spectroscopy (FT-IR) are powerful tools with which to characterize organic materials and to evaluate the transformations in organic matter $[1,17]$. Although information about organic matter interactions with metals is abundant [10], few studies that have used spectroscopic techniques to identify the molecular structural variations in organic amendments due to metal binding and the $\mathrm{pH}$ effect through changes in signals associated with their functional groups $[7,18]$.

The aims of this work were to analyze and compare the chemical structures and long-term stability of commercial humic substances and other organic amendments from different organic waste using spectroscopic and thermal analyses in order to evaluate their potential application in the remediation of agricultural soils. The interactions between $\mathrm{Cu}$ and some of these organic materials were also studied through a batch adsorption experiment, and observations of changes in their molecular structures were made using spectroscopic techniques to elucidate the main sorption mechanisms involved, and to determine the influence of $\mathrm{pH}$ conditions. We hypothesized that these organic amendments may interact with $\mathrm{Cu}$, especially at high $\mathrm{pH}$, by metal complexation of oxygen-containing functional groups, such as carboxylic and phenolic groups, showing observable changes of intensity and shifts in the NMR and FT-IR signals associated with such functional groups under different $\mathrm{Cu}$ and $\mathrm{pH}$ conditions.

\section{Materials and Methods}

\subsection{Organic Amendments}

Five organic materials were selected for this study:

HS: a solid humic substance product derived from American leonardite provided by a commercial supplier (product Humitec ExtraDry®, Tradecorp $®$, Madrid, Spain). It consisted of a black fine powder of potassium humates obtained through the extraction of natural humic substances from leonardite with $\mathrm{KOH}$. It was composed of humic $(53 \% w / w)$ and fulvic $(12 \%)$ acids (data provided 
by the supplier), with a $\mathrm{pH}$ of 11.2 and an electrical conductivity (EC) of $58.4 \mathrm{dS} \mathrm{m}^{-1}$ (water extract $1 / 5 v / v)$.

PW: pruning waste compost, composed of $60-70 \%(v / v)$ woody materials obtained from different kind of trees mixed with green waste such as grass, leaves, or flower cuttings. It was composted for 4 weeks, followed by 6 months during which it was piled in the 'Migas Calientes' municipal composting plant of Madrid (Spain). The $\mathrm{pH}$ was 8.3 and the EC was $1.1 \mathrm{dS} \mathrm{m}^{-1}$ (water extract $1 / 5 \mathrm{v} / \mathrm{v}$ ).

VC: vermicompost, made of cattle manure mixed with garden green waste; both were obtained from the facilities of the Agricultural Engineering School of the Universidad Politécnica de Madrid. The material was previously composted for 60 days, and then placed in a bed covered with straw. Then, a population of 1000 Eisenia fetida (Savygni) earthworms were integrated, allowing the material to be vermicomposted for 10 weeks. The $\mathrm{pH}$ was 9.0 and its EC was $0.5 \mathrm{dS} \mathrm{m}^{-1}$ (water extract $1 / 5 \mathrm{v} / \mathrm{v}$ ).

PB: compost of pine bark $(50 \% v / v)$, wood fiber $(30 \%)$, and Sphagnum peat $(20 \%)$, which was composted in an open-air composting plant located in Donhierro (Segovia, Spain) for 9-10 months, with a $\mathrm{pH}$ of 5.7 and a low EC, i.e., $0.7 \mathrm{dS} \mathrm{m}^{-1}$ (water extract $1 / 5 \mathrm{v} / \mathrm{v}$ ).

M: compost of sheep $(50 \% v / v)$ and horse $(50 \%)$ manure, also produced in the Donhierro plant and composted for $4-5$ months. Its $\mathrm{pH}$ was 8.5 and $\mathrm{EC}$ was $4.5 \mathrm{dS} \mathrm{m}^{-1}$ (water extract $1 / 5 \mathrm{v} / \mathrm{v}$ ).

\subsection{Elemental Analysis}

The contents in $\mathrm{C}, \mathrm{H}, \mathrm{N}$, and $\mathrm{S}$ of the organic amendments were determined using a LECO CHNS-932 elemental analyzer (LECO, St. Joseph, MI, USA). The oxygen content was calculated by the difference, considering $\mathrm{O} \%+\mathrm{C} \%+\mathrm{H} \%+\mathrm{N} \%+\mathrm{S} \%=100$. The atomic ratios of $\mathrm{C} / \mathrm{N}, \mathrm{H} / \mathrm{C}$, and $\mathrm{C} / \mathrm{O}$ were obtained as quotients of the contents of these elements considering their standard atomic weights.

\subsection{Solid-State ${ }^{13}$ C CPMAS NMR Analysis}

The Solid-State ${ }^{13} \mathrm{C}$ CPMAS NMR spectra were carried out on a Bruker WB-400 spectrometer (Bruker, Germany) at $300 \mathrm{~K}$. Samples were packed in a $4 \mathrm{~mm}$ diameter zirconium rotor with a Kel-F cap. The rotor spin rate was set at $12 \mathrm{kHz}$. For each sample of about $100 \mathrm{mg}$, between 20,000 and 40,000 scans were accumulated with a relaxation delay of $5 \mathrm{~ms}$ and a contact time of $2 \mathrm{~ms}$.

The NMR spectra were then baseline corrected and integrated into the following chemical-shift regions: 0-45 ppm alkyl C; 45-60 ppm N-alkyl C; 60-95 ppm O-alkyl C; 95-110 ppm di-O-alkyl C; 110-140 ppm aromatic C; 140-160 ppm phenolic C; 160-190 ppm carboxyl C; and 190-220 ppm carbonyl C [19]. Total aliphatic $C$ was calculated as the sum of percentages of Alkyl, N-Alkyl, O-Alkyl, and Di-O-Alkyl (0-110 ppm), and the total aromatic $C$ was calculated as the sum of aromatic and phenolic compounds (110-160 ppm) [20].

\subsection{FT-IR Analysis}

The FT-IR spectra of the amendments were determined with a FT-IR Bruker IFS66v spectrometer that works under vacuum conditions to avoid atmospheric interference. The spectra were taken over the range of 7000 and $500 \mathrm{~cm}^{-1}$ at a resolution of $1 \mathrm{~cm}^{-1}$. Samples of $2 \mathrm{mg}$ were ground and mixed with $98 \mathrm{mg}$ of $\mathrm{KBr}$ in an agate mortar. The spectra comprised 250 scans at a resolution of $4 \mathrm{~cm}^{-1}$.

\subsection{Thermal Analysis (DSC)}

A thermal analysis was performed using a DSC Q100 (TA Instruments, New Castle, DE, USA). The DSC analysis was performed with $7.258 \mathrm{mg}$ of M, $5.970 \mathrm{mg}$ of HS, $3.375 \mathrm{mg}$ of PB, $8.129 \mathrm{mg}$ of $\mathrm{PW}$, and $6.445 \mathrm{mg}$ of VC, placed in open aluminum pans. Samples of indium were used to calibrate the calorimeter.

Combustion took place under oxidative conditions within a temperature range from 25 to $600{ }^{\circ} \mathrm{C}$ and a constant heating rate of $10{ }^{\circ} \mathrm{C} \mathrm{min}{ }^{-1}$. The heat of combustion $\mathrm{Q}\left(\mathrm{J} \mathrm{g}^{-1}\right)$ was determined by integrating the DSC curves (in $\mathrm{W} \mathrm{g}^{-1}$ ) over the exothermic region $\left(150-600^{\circ} \mathrm{C}\right)$. Data below $150^{\circ} \mathrm{C}$ 
were discarded owing to residual moisture loss. The areas under the DSC curves were divided into three groups representing different degrees of resistance to thermal oxidation [16]: (a) 200-375 ${ }^{\circ} \mathrm{C}$, this fraction is attributable to labile organic matter, mainly comprising carbohydrates and other aliphatic compounds such as cellulose, lipids, and amino acids; (b) $375-475^{\circ} \mathrm{C}$, mostly attributable to recalcitrant organic matter, such as lignin or other polyphenols; and (c) $475-550^{\circ} \mathrm{C}$, corresponding mainly to highly recalcitrant organic matter, such as polycondensed aromatic substances.

\subsection{Study of Cu Interaction with Organic Amendments}

A batch adsorption experiment was performed with $\mathrm{HS}$ and $\mathrm{M}$ to study the interactions of these materials with different concentrations of $\mathrm{Cu}$, which was based on previous works [8,9].

The experiment was performed under different $\mathrm{pH}$ conditions $(2.5,5.0$ and 8.0$)$ to study the influence of $\mathrm{pH}$ on $\mathrm{Cu}$ sorption onto organic materials. However, data from $\mathrm{pH} 8.0$ were finally dismissed due to $\mathrm{Cu}$ precipitation.

The batch experiment was carried out in triplicate using $40 \mathrm{~mL}$ polyethylene centrifuge tubes containing $0.5 \mathrm{~g}$ of sample (HS or M) and $20 \mathrm{~mL}$ of deionized water. The $\mathrm{pH}$ was initially adjusted (micropH $2000 \mathrm{pH}$ meter, Crison, Spain) to 2.5, 5.0, or 8.0 by the addition of diluted $\mathrm{NaOH}$ or $\mathrm{HCl}$, and samples were shaken for $1 \mathrm{~h}$.

After shaking, the required amount of $\mathrm{Cu}\left(0 \mathrm{mg} \mathrm{L}^{-1}\right.$ as control, $\mathrm{HSO}$ and M0; and a treatment with $100 \mathrm{mg} \mathrm{L}^{-1}$ equivalent to $5000 \mathrm{mg} \mathrm{kg}^{-1}$, HS100 and M100) was added from a stock solution of $\mathrm{CuCl}_{2}$ ( $2500 \mathrm{mg} \mathrm{L}^{-1}$ of $\mathrm{Cu}$ ) dissolved in deionized water.

After $\mathrm{Cu}$ addition, the ionic strength was adjusted (microCM 2200 conductivity meter, Crison, Spain) by the addition of $0.5 \mathrm{M} \mathrm{NaCl}$ using a reference solution of $0.3 \mathrm{M} \mathrm{NaCl}$. The suspension was made up to $25 \mathrm{~mL}$ and the $\mathrm{pH}$ was readjusted. Samples were then shaken again for $24 \mathrm{~h}$ and centrifuged at $9000 \times g$ for $30 \mathrm{~min}$. The solid residue was collected in ceramic crucibles that were sealed with paraffin film and frozen for two days; then, these samples were freeze-dried using a Telstar Cryodos (Telstar, Spain) for $48 \mathrm{~h}$ at $-40{ }^{\circ} \mathrm{C}$ and a pressure between 0.01 and 0.3 mbars. The freeze-dried material of all three replications of the same $\mathrm{pH}$ and $\mathrm{Cu}$ concentration treatment was collected together to be analyzed by ${ }^{13} \mathrm{C}$ CPMAS NMR and FT-IR techniques, as described in Sections 2.3 and 2.4.

\section{Results and Discussion}

\subsection{Initial Characterization of the Organic Amendments}

\subsubsection{Elemental Analysis}

The results of the elemental analysis (Table 1) showed that HS and PB had the highest carbon content, whereas $\mathrm{M}$ had the lowest. A high $\mathrm{C} / \mathrm{N}$ ratio suggests a high stability and condensation degree, as well as an extended humification degree of organic matter [21,22]. The amendments HS and $\mathrm{PB}$ showed the highest $\mathrm{C} / \mathrm{N}$ values, which agreed with the stability conferred by the presence of recalcitrant organic matter and low content in labile organic matter revealed by their thermal analysis (see Section 3.1.4). In contrast, the lowest $\mathrm{C} / \mathrm{N}$ ratio was shown by $\mathrm{M}$, since manure usually has a high $\mathrm{N}$ content [23], with a thermogram (Section 3.1.4) showing a high content in labile organic matter.

Table 1. Elemental analysis and atomic ratios of the organic amendments.

\begin{tabular}{ccccccccc}
\hline Organic Amend. $^{\mathbf{1}}$ & $\mathbf{\% \mathbf { C }}$ & $\mathbf{\% H}$ & $\mathbf{\% N}$ & $\mathbf{\% S}$ & $\mathbf{\% O}$ & $\mathbf{C} / \mathbf{N}$ & $\mathbf{H} / \mathbf{C}$ & $\mathbf{C} / \mathbf{O}$ \\
\hline HS & 33.5 & 3.4 & 0.6 & 0.53 & 62.0 & 65.1 & 1.22 & 0.72 \\
PW & 30.1 & 3.9 & 2.1 & 0.10 & 63.9 & 16.7 & 1.55 & 0.63 \\
VC & 26.2 & 3.6 & 2.2 & 0.21 & 67.8 & 13.9 & 1.65 & 0.52 \\
PB & 35.7 & 4.2 & 0.5 & 0.04 & 59.7 & 83.3 & 1.41 & 0.80 \\
M & 13.3 & 1.9 & 1.4 & 0.21 & 83.1 & 11.1 & 1.71 & 0.21 \\
\hline
\end{tabular}

1 HS: humic substances; PW: pruning waste compost; VC: vermicompost; PB: pine bark compost; M: sheep and horse manure compost. 
The $\mathrm{H} / \mathrm{C}$ ratio represents the aliphaticity of the organic matter. High $\mathrm{H} / \mathrm{C}$ values indicate that the organic matter is mainly aliphatic, whereas low values indicate a high content of aromatic compounds $[21,24,25]$. These $\mathrm{H} / \mathrm{C}$ ratios generally correlated with the results obtained from NMR analysis (Section 3.1.2), with HS and PB being the amendments with lowest aliphaticity and most aromaticity. Soler-Rovira et al. [2] reported negative correlations between the $\mathrm{H} / \mathrm{C}$ ratio and the $\mathrm{Cu}$ complexion capacity of humic substances due to the greater contribution of aromatic functional groups for the adsorption of $\mathrm{Cu}$ compared to aliphatic. Other authors found negative correlations between the $\mathrm{H} / \mathrm{C}$ and N/C ratios of humic substances with thermal stability [26,27], showing a higher degree of stability of HS and PB and a lower one for M, which agreed with the results obtained from the DSC analysis of these amendments (Section 3.1.4).

On the other hand, the $\mathrm{C} / \mathrm{O}$ ratio is an indicator of polarity due to the presence of polar functional groups, such as carboxyl or phenolic; a low $\mathrm{C} / \mathrm{O}$ ratio indicates a high polarity, which could be an indicator of a better ability to interact with metals [25,28]. Among the amendments, HS and PB were the least polar, while $\mathrm{M}$ was the most.

\subsubsection{Solid state ${ }^{13} \mathrm{C}$ CPMAS NMR Spectra}

Comparing the spectra of the five organic amendments, it was observed that HS exhibited a different spectrum (Figure S1), suggesting that this amendment had a considerably different chemical structure. The main peaks of the spectra were integrated and the results are shown in Table 2.

Table 2. Relative areas (\% of total area) of the chemical shift (ppm) regions in ${ }^{13} \mathrm{C} C$ CMAS NMR spectra of organic amendments.

\begin{tabular}{ccccccccccc}
\hline $\begin{array}{c}\text { Organic } \\
\text { Amend. }\end{array}$ & $\begin{array}{c}{ }^{\mathbf{0}} \mathbf{- 4 5} \\
\text { Alkyl }\end{array}$ & $\begin{array}{c}\mathbf{4 5 - 6 0} \\
\text { N-Alkyl }\end{array}$ & $\begin{array}{c}\mathbf{6 0 - 9 5} \\
\text { O-Alkyl }\end{array}$ & $\begin{array}{c}\mathbf{9 5 - 1 1 0} \\
\text { Di-O-Alkyl }\end{array}$ & $\begin{array}{c}\mathbf{1 1 0 - 1 4 0} \\
\text { Aromatic }\end{array}$ & $\begin{array}{c}\mathbf{1 4 0 - 1 6 0} \\
\text { Phenolic }\end{array}$ & $\begin{array}{c}\mathbf{1 6 0 - 1 9 0} \\
\text { Carboxyl }\end{array}$ & $\begin{array}{c}\mathbf{1 9 0 - 2 2 0} \\
\text { Carbonyl }\end{array}$ & Aliphatic & Aromatic \\
\hline HS & 34.2 & 9.0 & 9.5 & 0.0 & 29.6 & 10.1 & 7.5 & 0.0 & 52.7 & 39.7 \\
PW & 18.3 & 12.5 & 34.2 & 10.0 & 12.5 & 6.7 & 5.8 & 0.0 & 75.0 & 19.2 \\
VC & 17.8 & 11.1 & 31.1 & 8.9 & 13.3 & 7.8 & 10.0 & 0.0 & 68.9 & 21.1 \\
PB & 6.3 & 5.5 & 44.5 & 11.0 & 17.7 & 10.2 & 3.1 & 1.6 & 67.3 & 27.9 \\
M & 16.8 & 11.4 & 35.9 & 8.2 & 15.9 & 7.3 & 4.5 & 0.0 & 72.3 & 23.2 \\
\hline
\end{tabular}

${ }^{1}$ HS: humic substances; PW: pruning waste compost; VC: vermicompost; PB: pine bark compost; M: sheep and horse manure compost.

It can be observed that the highest content in aliphatic C occurred in PW $(75.0 \%)$, followed by M (72.3\%); HS (52.7\%) and PB (67.3\%) had the lowest. Tapia et al. [3] also found a higher aliphatic C content in pruning waste and a lower one in pine bark compost in comparison to other organic amendments. Despite the lowest total content of aliphatic $\mathrm{C}$ in HS, this amendment presented the highest content in long-chain aliphatic compounds (alkyl, $0-45 \mathrm{ppm}, 34.2 \%$ ). Large signals in this aliphatic region may be produced by the presence of fatty acids and humic acids with aliphatic structures or the presence of recalcitrant hydrophobic components related to cutin and suberin $[3,17,29]$. In contrast, PB exhibited the lowest signal in this alkyl region (0-45 ppm, 6.3\%), but the highest in carbohydrates such as cellulose and hemicellulose (O-alkyl, 60-95 ppm, 44.5\%), whereas HS had a considerably lower content (60-95 ppm, 9.5\%) compared to the other amendments. These alkyl groups are usually degraded during composting, producing aromatic, phenolic, and carboxylic groups [3,29,30]. However, PB might have undergone less change than the others during composting, which correlates with the high $\mathrm{C} / \mathrm{N}$ ratio of PB (Table 1) and the low carboxyl content of this amendment (Table 2). Similar results were observed by Tapia et al. [3] in pine bark compost compared with other amendments.

The HS had the highest aromatic C content (39.7\%), especially in the region at 110-140 ppm, where there is a peak at $128 \mathrm{ppm}$ (Figure S1) which may be attributed to $\mathrm{C}$ and $\mathrm{H}$ substituted aromatic $\mathrm{C}$ in lignin. The phenol content (140-160 ppm) was quite similar in all amendments, although it was slightly higher in HS and PB. These aromatic structures are known to be involved in the reactions between metals and humic substances $[7,24,25]$. 
In the region assigned to carboxylic groups (160-190 ppm), HS and VC showed the highest amounts ( 7.5 and $10.0 \%$, respectively). It may be noted that both amendments could be useful to stabilize metals in contaminated soils, considering that carboxylic groups have the highest metal affinity [7].

Regarding the carbonyl region (190-220 ppm), there were no appreciable signals in these amendments, except a low PB content. Other authors have also reported the absence of carbonyl groups, attributed to aldehydes, ketones, and quinones, in humic substances [31].

\subsubsection{FT-IR Spectra}

All the amendments exhibited different FT-IR spectra, especially in the region below $1800 \mathrm{~cm}^{-1}$ (see Figure 1), with HS showing most pronounced differences in the NMR analysis, suggesting a dissimilar chemical structure of this amendment.

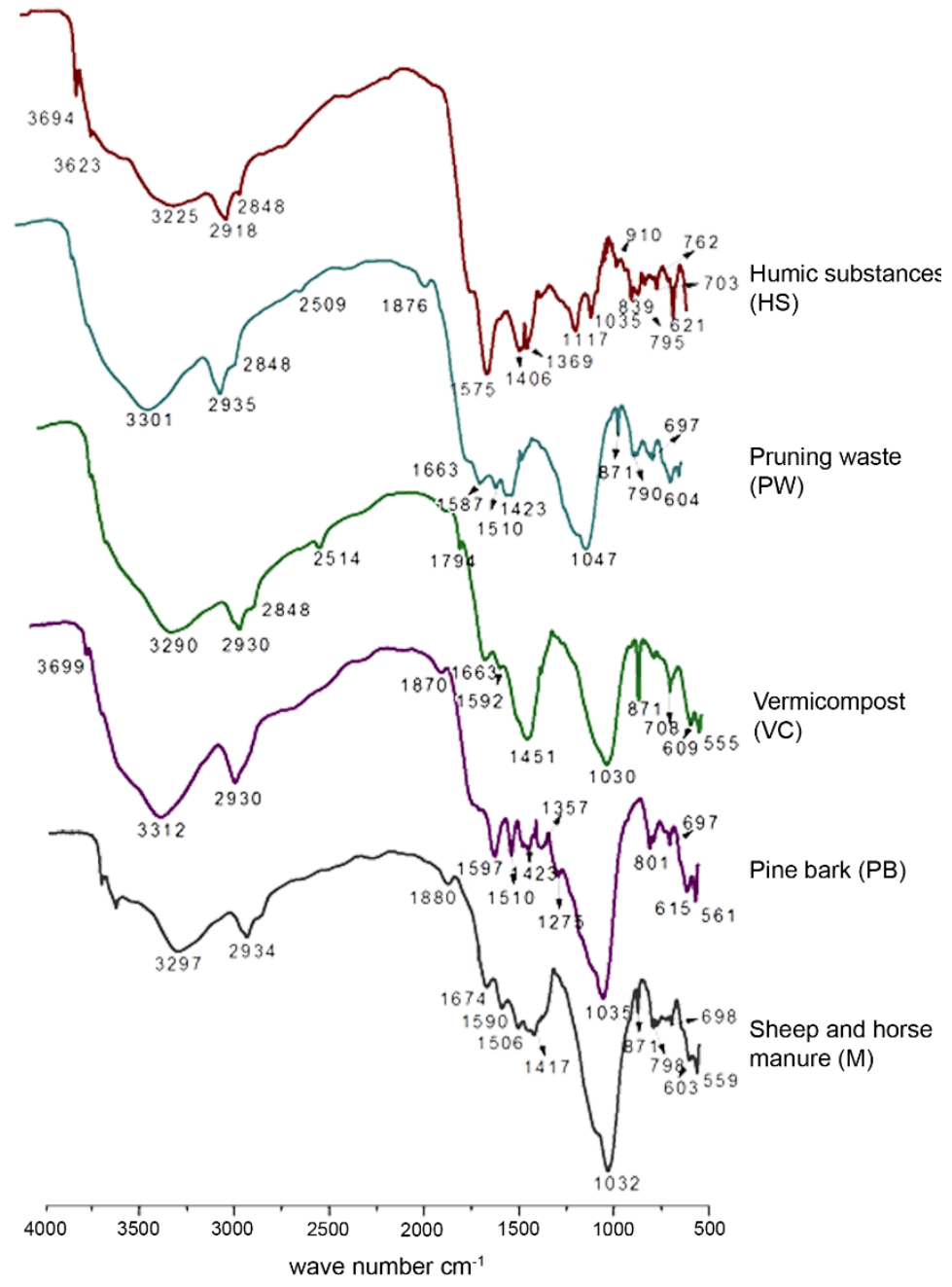

Figure 1. FT-IR spectra of organic amendments.

Every amendment showed a band at around $3300 \mathrm{~cm}^{-1}$ which corresponded to the H-bonded $\mathrm{O}-\mathrm{H}$ stretching of carboxyl, phenol, and alcohol. All the amendments exhibited another band at around $2930 \mathrm{~cm}^{-1}$, and $\mathrm{PW}, \mathrm{VC}$, and HS showed another at $2848 \mathrm{~cm}^{-1}$, representing the stretching of $\mathrm{C}-\mathrm{H}$ in the $-\mathrm{CH}_{3}$ and $-\mathrm{CH}_{2}$ of aliphatic structures $[2,3,11,32,33]$.

Additionally, a band was shown at $1663-1674 \mathrm{~cm}^{-1}$ in $\mathrm{PW}, \mathrm{VC}$, and $\mathrm{M}$ that represents the $\mathrm{C}=\mathrm{O}$ stretching of amide groups (amide I band). The spectra of $\mathrm{PW}, \mathrm{PB}$, and $\mathrm{M}$ showed a band around $1510 \mathrm{~cm}^{-1}$ which is attributable to the $\mathrm{C}=\mathrm{N}$ stretching of amides (amide II band), COO- symmetric 
stretching, and N-H deformation. Every amendment also showed a band at $1575-1597 \mathrm{~cm}^{-1}$ which was most intense in HS; this band was attributed to the aromatic $\mathrm{C}=\mathrm{C}$ and $\mathrm{C}=\mathrm{O}$ stretch of $\mathrm{H}$-bonded ketones and carboxylate groups $[2,9,11,20,32,33]$.

All the spectra had a signal between 1406 and $1451 \mathrm{~cm}^{-1}$, while PB and HS showed another at around $1360 \mathrm{~cm}^{-1}$, corresponding to the -COO- antisymmetric stretching of carboxylic acids, $-\mathrm{O}-\mathrm{H}-$ deformation, and the $\mathrm{C}-\mathrm{O}$ stretching of phenols and $\mathrm{C}-\mathrm{H}$ deformation of $-\mathrm{CH}_{3}[2,11,20,32,33]$.

There was a peak that appeared in $\mathrm{PB}$ at $1275 \mathrm{~cm}^{-1}$, which may be attributed to the C-O stretching and $\mathrm{O}-\mathrm{H}$ bending deformation of carboxylic groups, as well as the $\mathrm{C}-\mathrm{O}$ stretching of aryl ethers and -C-N- stretching of amide groups (amide III) [2,11,20,32,33]. Sn appreciable peak at $1117 \mathrm{~cm}^{-1}$ in HS could be also observed, corresponding to aromatic ring bending and -C-O-C stretching of alkyl ethers [32], which indicates a high degree of humification due to its great content in humic acids, according to Tapia et al. [3].

All the amendments showed an intense band between 1030 and $1047 \mathrm{~cm}^{-1}$, attributable to stretching vibrations of -C-O- of aromatic and aryl ethers and alcohols, as well as of polysaccharides $[2,3,11,32,33]$; this was also shown in the NMR spectra (see Table 2). However, this band was less intense in HS, reflecting the presence of significant levels of labile compounds such as cellulose and hemicellulose carbohydrates in all the studied amendments except HS.

Finally, every amendment had several bands between 762 and $910 \mathrm{~cm}^{-1}$ that could be attributed to the out-of-plane bending of aromatic C-H $[32,33]$, and some bands at $60-700 \mathrm{~cm}^{-1}$ that correspond to aromatic ring bending [32].

\subsubsection{DSC Thermal Analysis}

A thermal analysis of HS (see Figure 2) showed some endothermic peaks below $200{ }^{\circ} \mathrm{C}$, which are attributed to dehydration processes, the thermal decarboxylation of acid groups, and/or to the loss of peripheral polysaccharide chains [11-15,26]. The HS amendment also showed small exothermic shoulders at around $300{ }^{\circ} \mathrm{C}$ (labile organic matter) and $400{ }^{\circ} \mathrm{C}$ (recalcitrant organic matter), as well as another at $500{ }^{\circ} \mathrm{C}$, that is attributed to the oxidation and polycondensation of the aromatic nuclei of humic molecules, corresponding to highly thermostable and recalcitrant lignin structures [11-16,26].

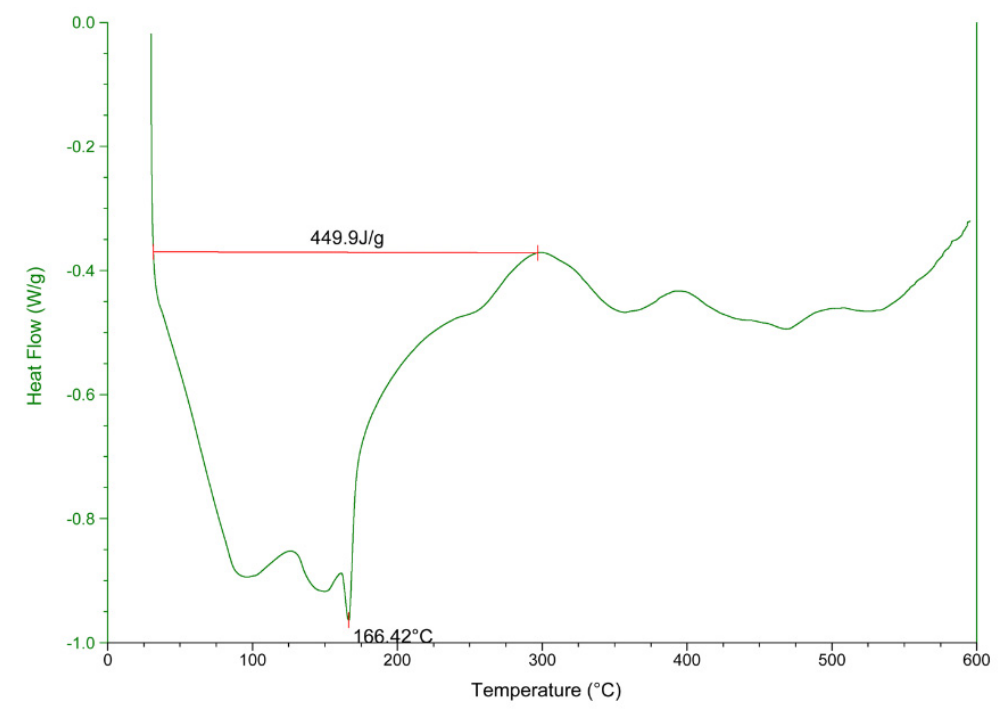

Figure 2. DSC thermal analysis of the humic substances (HS).

Thermograms of PW (Figure 3), VC (Figure 4), PB (Figure 5), and M (Figure 6) showed an exothermic peak between 310 and $335{ }^{\circ} \mathrm{C}$, which is considered labile organic matter [16] and is attributed to the loss of amidic groups of polypeptidic structures and the combustion of carbohydrates and other aliphatic compounds $[12-15,26]$. The authors suggested that this exotherm is related to 
the humification status of organic materials, because its intensity decreases with composting time due to the incorporation and stabilization of peptidic structures in the humic molecules. The most intense peak was shown by $\mathrm{M}$, indicating its high carbohydrate content, which agreed with our FT-IR (see Figure 1) and ${ }^{13} \mathrm{C}$ CPMAS NMR analyses (see Table 2).

There were other peaks between 430 and $479{ }^{\circ} \mathrm{C}$ which are attributable to the oxidation of aromatic carbons like lignin or polyphenols, and are considered as recalcitrant organic matter $[16,26]$. In the cases of VC, PB, and PW, these peaks were sharp and narrow, and are frequently associated with soil organic matter precursors such as plant leaves, which are usually present as two or more well-separated peaks between 460 and $480{ }^{\circ} \mathrm{C}$ [26].

Thermograms of HS and PW showed an exothermic peak between 475 and $550{ }^{\circ} \mathrm{C}$ which is attributable to the highly recalcitrant forms of organic matter, such as polycondensed aromatic compounds (humic acids, humin, and black carbon) [11-16,26].

Comparing the thermal analyses of the five studied amendments, it was observed that $\mathrm{M}$ had the highest content in labile organic matter, resulting the least stable amendment. Conversely, the amendments with the highest content in highly recalcitrant organic matter were PW and HS, making them the most stable and able to retain metals over long periods of time.

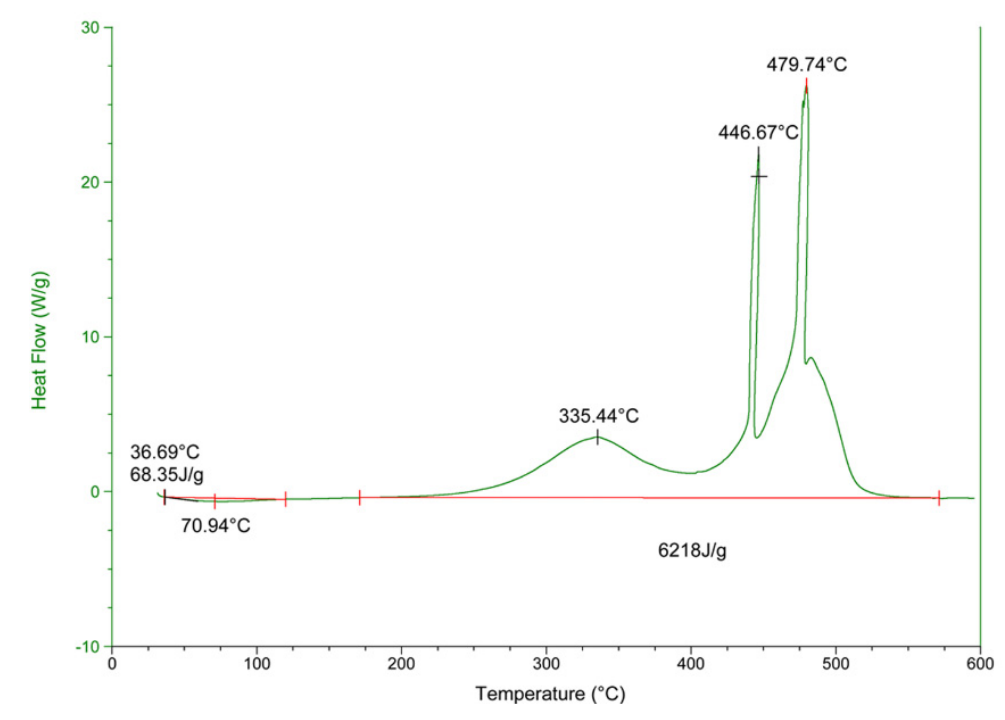

Figure 3. DSC thermal analysis of the pruning waste compost (PW).

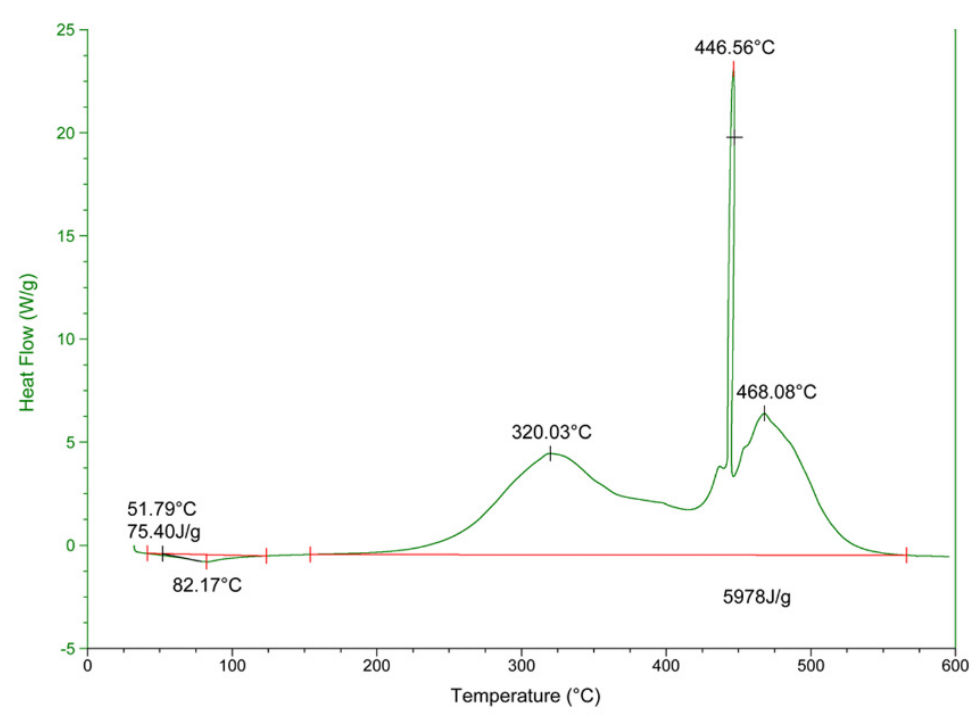

Figure 4. DSC thermal analysis of the vermicompost (VC). 


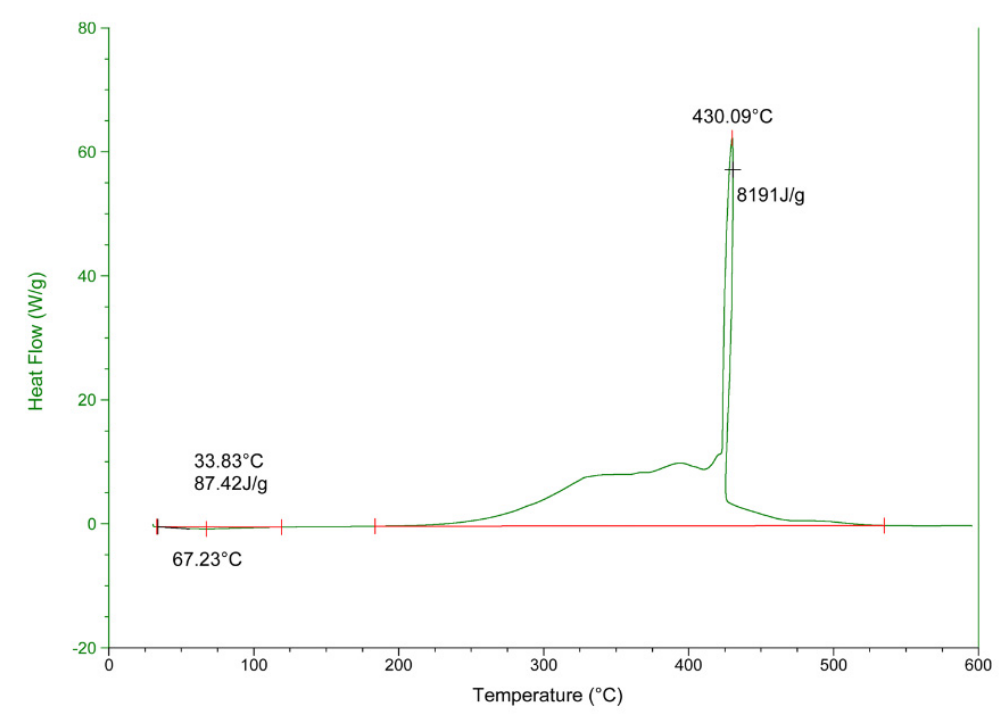

Figure 5. DSC thermal analysis of the pine bark compost (PB).

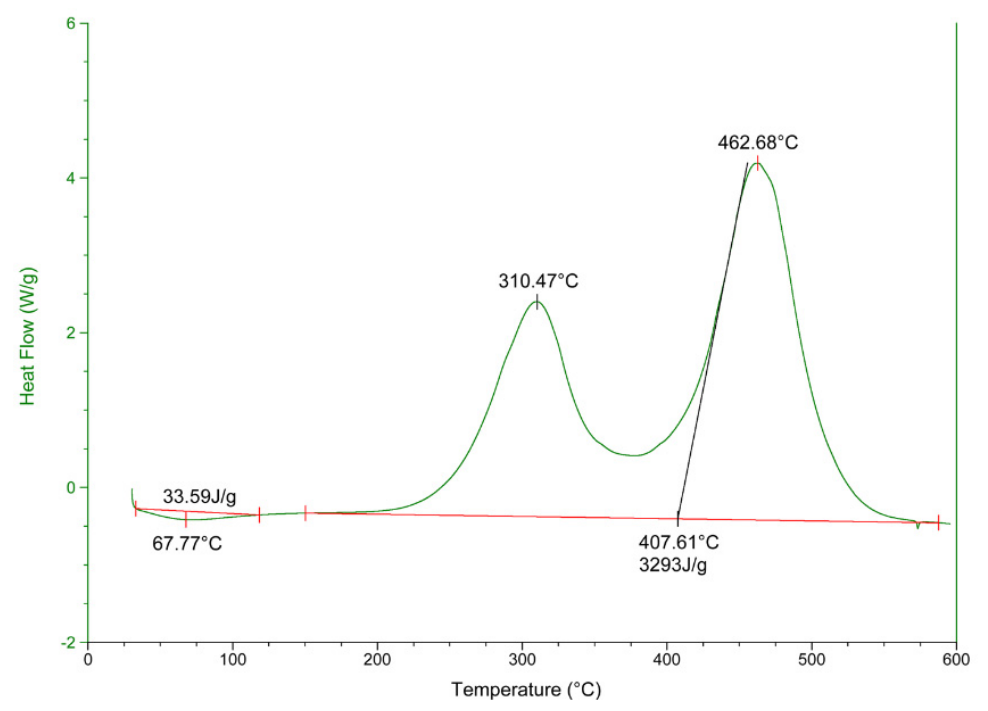

Figure 6. DSC thermal analysis of the sheep and horse manure compost (M).

\subsection{Interaction of $\mathrm{Cu}$ with Organic Amendments}

After the spectroscopic and DSC characterization of the organic amendments, it can be concluded that $\mathrm{M}$ showed considerably different structural characteristics than HS. Thus, these two organic materials were selected to evaluate the adsorption of copper on their functional groups and to determine the influence of $\mathrm{pH}$ conditions.

\subsubsection{Solid-state ${ }^{13} \mathrm{C} C$ PMAS NMR Analysis of the Interaction with $\mathrm{Cu}$}

Several works $[18,20,24,34-42]$ have previously used this technique to characterize humic substances, soil organic matter, or other organic materials after reactions with paramagnetic metals, such as $\mathrm{Cu}$, by observing changes in the signal intensities, relaxation rate changes, chemical shifts, and peak broadening attributable to the different functional groups involved in sorption mechanisms, such as carboxylic and phenolic groups, which interact strongly with $\mathrm{Cu}$ [7]. These changes reflect alterations in the electronic environment and in the relaxation rates of nuclei close to the paramagnetic metal ion [18]. Smernik and Oades [41] suggested that signal loss and broadening in solid-state ${ }^{13} \mathrm{C}$ NMR may be caused by the loss of magnetic field homogeneity affecting all ${ }^{13} \mathrm{C}$ nuclei non-selectively; however, when the ferromagnetic species is present in organo-mineral complexes or at cation exchange 
sites, it induces selective signal losses localized to the close environment of the ferromagnetic species via interactions between electronic and nuclear spins, as is the case with $\mathrm{Cu}$, due to its high affinity for organic matter. Additionally, $\mathrm{pH}$ can also modify these signals by changes in chemical shifts due to the different degree of dissociation of the functional groups under different $\mathrm{pH}$ conditions [43].

The ${ }^{13} \mathrm{C}$ NMR spectra of HS samples are shown in Figure S2, and the results from a semi-quantitative analysis of their functional groups is shown in Table 3.

Table 3. Relative areas (\% of total area) of the chemical shift (ppm) regions in ${ }^{13} \mathrm{C} C$ CMAS NMR spectra in humic substances (HS) and sheep and horse manure compost (M) at pH 2.5 and 5.0.

\begin{tabular}{ccccccccc}
\hline Treatment $^{1}$ & $\begin{array}{c}\mathbf{0 - 4 5} \\
\text { Alkyl }\end{array}$ & $\begin{array}{c}\mathbf{4 5 - 6 0} \\
\text { N-Alkyl }\end{array}$ & $\begin{array}{c}\mathbf{6 0 - 9 5} \\
\text { O-Alkyl }\end{array}$ & $\begin{array}{c}\mathbf{9 5 - 1 1 0} \\
\text { Di-O-Alkyl }\end{array}$ & $\begin{array}{c}\mathbf{1 1 0 - 1 4 0} \\
\text { Aromatic }\end{array}$ & $\begin{array}{c}\mathbf{1 4 0 - 1 6 0} \\
\text { Phenolic }\end{array}$ & $\begin{array}{c}\mathbf{1 6 0 - 1 9 0} \\
\text { Carboxyl }\end{array}$ & $\begin{array}{c}\mathbf{1 9 0 - 2 2 0} \\
\text { Carbonyl }\end{array}$ \\
\hline HS0 pH 5.0 & 48.4 & 4.8 & 4.1 & 3.3 & 27.9 & 7.4 & 4.1 & 0.0 \\
HS100 pH 5.0 & 42.4 & 7.6 & 5.9 & 4.3 & 27.9 & 8.5 & 3.4 & 0.0 \\
HS0 pH 2.5 & 23.4 & 5.5 & 6.2 & 6.9 & 36.6 & 13.8 & 7.6 & 0.0 \\
HS100 pH 2.5 & 22.7 & 5.2 & 5.2 & 6.2 & 38.1 & 14.4 & 8.2 & 0.0 \\
M0 pH 5.0 & 13.7 & 10.8 & 29.6 & 8.1 & 18.8 & 9.9 & 6.3 & 2.8 \\
M100 pH 5.0 & 12.5 & 10.6 & 35.9 & 8.0 & 17.9 & 9.7 & 5.4 & 0.0 \\
M0 pH 2.5 & 15.6 & 12.2 & 30.4 & 7.8 & 19.2 & 9.6 & 5.2 & 0.0 \\
M100 pH 2.5 & 16.8 & 11.8 & 31.1 & 7.6 & 17.6 & 10.1 & 5.0 & 0.0 \\
\hline
\end{tabular}

${ }^{1} \mathrm{HS} 0$ and M0: organic amendment treated with solution of $0 \mathrm{mg} \mathrm{L}^{-1}$ of $\mathrm{Cu} ; \mathrm{HS} 100$ and M100: organic amendment treated with solution of $100 \mathrm{mg} \mathrm{L}^{-1}$ of $\mathrm{Cu}$.

In the aliphatic region, the treatments of $\mathrm{HS}$ at $\mathrm{pH} 5.0$ showed a considerably higher signal in alkyl (0-45 ppm) and a slightly lower in di-O-alkyl (95-110 ppm) compared with those at $\mathrm{pH} 2.5$. However, there were no clear trends in N-alkyl (45-60 ppm) and O-alkyl (60-95) with $\mathrm{pH}$. Regarding differences between $\mathrm{Cu}$ concentrations, HS experienced an important decrease in the alkyl region with increasing $\mathrm{Cu}$ at $\mathrm{pH}$ 5.0. Sh et al. [34] also reported a significant decrease in alkyl $\mathrm{C}$ due to metal binding by aliphatic protons. Other authors also suggested that signal losses in this alkyl region could be due to important binding sites consisting of carboxyl groups clustered in short-chain aliphatic dibasic structures $[18,35,38]$. In contrast, there was an increase in the other aliphatic regions with higher $\mathrm{Cu}$ at $\mathrm{pH}$ 5.0, especially in $\mathrm{N}$-alkyl. Other works have suggested that the adsorption phenomena in humic substances under relatively low $\mathrm{pH}$ conditions, e.g., $\mathrm{pH} 4-5$, could be due to the complexation of $\mathrm{Cu}$ with nitrogen-containing groups, like this $\mathrm{N}$-alkyl region [8]. Changes in the O-alkyl (60-95) and Di-O-alkyl (95-110) regions with Cu could be the result of binding by carbohydrates such as uronic acids $[36,38,41]$. At $\mathrm{pH} 2.5$, the signal changes with $\mathrm{Cu}$ in these aliphatic regions were not remarkable.

Regarding the aromatic region (110-140 ppm), its signal in HS was considerably lower at pH 5.0 than at $\mathrm{pH}$ 2.5. The aromatic content slightly increased with $\mathrm{Cu}$ concentration at $\mathrm{pH} 2.5$, but there were no important differences at $\mathrm{pH}$ 5.0. The phenolic region (140-160 ppm) in HS exhibited a lower signal at $\mathrm{pH} 5.0$, as was the case with the aromatic region, due to signal shifts caused by the ionization of these groups [43]. There was a slight increase in phenolic content with increasing $\mathrm{Cu}$ due to the involvement of this functional group in metal retention $[7,24]$, which was more pronounced at $\mathrm{pH} 5.0$ because of the lower proton competition and the higher negative charge by deprotonation $[8,25,44]$.

The carboxylic region (160-190 ppm) was also lower at $\mathrm{pH} 5.0$ due to signal shifts by its dissociation at a higher $\mathrm{pH}$ [43]. At $\mathrm{pH} 2.5$, there were no remarkable differences between $\mathrm{Cu}$ concentrations, given the high level of competition between $\mathrm{Cu}$ and protons and the reduced negative charge of functional groups, as explained above $[8,25,44]$. Nevertheless, there was a slight drop in HS100 compared with HSO at pH 5.0, which might be attributable to the strong interaction of $\mathrm{Cu}$ with this functional group, whose complexes are the preferred mechanism for $\mathrm{Cu}$ adsorption [7]. Similar results were obtained by previous authors $[20,24,34,35,39]$, who reported a reduction in the intensity of this carboxylic region with increasing metal loadings due to chemical shift or peak broadening caused by the formation of carboxyl-metal complexes. 
On the other hand, there were no appreciable peaks in the carbonyl region (190-220 ppm) in any of the studied samples of HS.

The NMR spectra of manure compost $(\mathrm{M})$ are shown in Figure S3; the contents in the different functional groups of its treatments are also shown in Table 3.

In the aliphatic region, there was a lower signal in alkyl and $\mathrm{N}$-alkyl in $\mathrm{M}$ at $\mathrm{pH} 5.0$ than at $\mathrm{pH} 2.5$, whereas $\mathrm{O}$-alkyl and di-O-alkyl were similar at both $\mathrm{pH}$ conditions, except for an observed increase of $\mathrm{O}-\mathrm{alkyl}$ in $\mathrm{M} 100$ at $\mathrm{pH}$ 5.0. If $\mathrm{Cu}$ concentrations are compared, it is noticeable that the O-alkyl signal increased with higher $\mathrm{Cu}$ concentrations at $\mathrm{pH}$ 5.0, as was the case with HS, whereas the other regions (alkyl, $\mathrm{N}$-alkyl, and di-O-alkyl) did not experience such remarkable differences with $\mathrm{Cu}$, i.e., neither at pH 2.5 nor at $\mathrm{pH} 5.0$.

The signals of aromatic and phenolic groups in $\mathrm{M}$ were similar at $\mathrm{pH} 2.5$ and $\mathrm{pH}$ 5.0, showing that the signals were not affected by the ionization of these groups, contrary to what happened in HS. Comparing $\mathrm{Cu}$ concentrations, the signal in the aromatic groups slightly decreased with increasing $\mathrm{Cu}$ at both $\mathrm{pH}$ conditions, whereas phenolic remained similar.

The carboxylic signal was slightly higher at $\mathrm{pH} 5.0$ than at $\mathrm{pH} 2.5$. Additionally, a slight decrease in this carboxylic region in M100 could be appreciated when compared with M0, mainly at $\mathrm{pH} 5.0$, which might be indicative of a greater extent of complexation of $\mathrm{Cu}$ with this functional group when it is deprotonated, as was the case with HS. These changes with $\mathrm{Cu}$ in the carboxylic group but not in the phenolic group suggests a stronger metal binding capacity of the low proton affinity sites (carboxylic-type) of humic substances than the high proton affinity sites (phenolic-type), as defined by the NICA-Donnan model [45].

Regarding the carbonyl region, $\mathrm{M} 0$ at $\mathrm{pH} 5.0$ showed a signal that did not occurr in the other treatments due to the possible presence of aldehydes and ketones.

The effects of $\mathrm{Cu}$ and $\mathrm{pH}$ on the signals of the different functional groups were considerably greater in HS than in M, which suggests a higher sorption capacity of HS through the formation of complexes with this metal, given its higher aromaticity and content in phenolic and carboxylic groups than $\mathrm{M}$. However, in HS, the effect of $\mathrm{pH}$ was greater than the presence of $\mathrm{Cu}$. The protonation/deprotonation of its functional groups play a more important role in the differences among NMR spectra. Preston and Schnitzer [43] reported the important contribution of $\mathrm{pH}$ to signal distortion in the ${ }^{13} \mathrm{C}$ spectra of humic substances, finding that a greater level of dissociation of carboxyl and phenolic groups with increasing $\mathrm{pH}$ moved their peaks downfield. This might explain the lower signals of carboxyl and phenolic and the higher of aliphatic groups observed in this study in $\mathrm{HS}$ at $\mathrm{pH} 5.0$ in comparison to $\mathrm{pH}$ 2.5 , probably due to a shift downfield from the former to the latter functional groups.

Additionally, it is noticeable that in both $\mathrm{HS}$ and $\mathrm{M}, \mathrm{Cu}$ effects were greater at $\mathrm{pH} 5.0$ than at $\mathrm{pH}$ 2.5. At low $\mathrm{pH}$, there may be a lower complexation of $\mathrm{Cu}$, and therefore, smaller differences in signals, probably due to the competence between $\mathrm{H}^{+}$and $\mathrm{Cu}^{2+}$ for the functional groups of the organic matter, or to a reduction of their negative charges by protonation $[8,25,44]$. Zhang et al. [24] also observed smaller effects in metal reactions with the functional groups of humic substances under low $\mathrm{pH}$ conditions.

\subsubsection{FT-IR Analysis of the Interaction with $\mathrm{Cu}$}

We also compared the FTIR spectra of the HS and M amendments under different $\mathrm{Cu}$ (HSO and HS100, M0, and M100) and $\mathrm{pH}$ conditions ( $\mathrm{pH} 2.5$ and 5.0).

The FT-IR spectra of the treatments with humic substances (HS) are shown in Figure 7.

In the spectra of HS treatments several peaks can be observed between $3220-3700 \mathrm{~cm}^{-1}$, attributable to the $\mathrm{O}-\mathrm{H}$ stretching of alcohols, phenols, and carboxyl $[3,11,32,33]$, whose intensity increased at pH 5.0 in comparison to pH 2.5. Signals of some of these peaks, i.e., around 3620 and $3690 \mathrm{~cm}^{-1}$, were lower in HS100 than in HSO at pH 5.0. This drop of absorption with increasing Cu suggests the binding of this metal by these $\mathrm{OH}$ groups, such as phenol and carboxyl. Boguta and Sokolowska [46] also observed decreasing intensities at these bands with the addition of $\mathrm{Zn}$ to different humic acids, 
due to metal binding by $\mathrm{OH}$ groups, whereas Boguta et al. [47] reported higher intensities with Fe because of the involvement of $\mathrm{OH}$ groups in metal complexation by the production of aqua-complexes. Álvarez-Puebla et al. [8] also observed changes in the signals of these bands due to the formation of complexes of $\mathrm{Cu}$ with carboxylic acid groups. Additionally, these authors suggested the formation of copper hydroxide at $\mathrm{pH} 4-6$, shown by the increased intensity of bands around $3300-3400 \mathrm{~cm}^{-1}$.

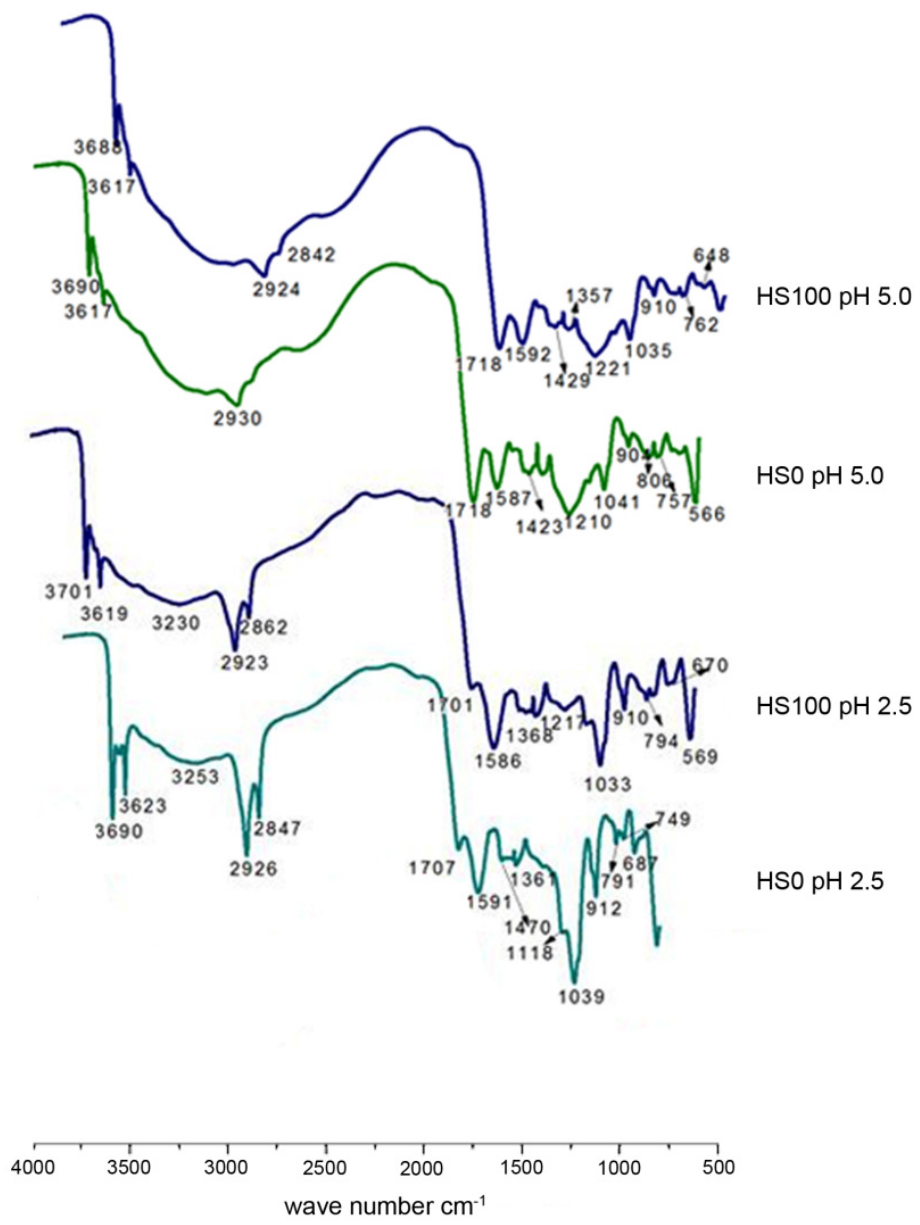

Figure 7. FT-IR spectra of humic substances with the addition of $0 \mathrm{mg} \mathrm{L}^{-1}$ of $\mathrm{Cu}(\mathrm{HSO})$ and $100 \mathrm{mg} \mathrm{L}^{-1}$ of $\mathrm{Cu}$ (HS100), adjusted to $\mathrm{pH} 2.5$ and $\mathrm{pH} 5.0$.

The intensity of bands between $2848-2930 \mathrm{~cm}^{-1}$, attributable to aliphatic $\mathrm{C}-\mathrm{H}[2,3,11,32,33]$, increased at $\mathrm{pH} 5.0$ compared to $\mathrm{pH}$ 2.5. These bands also decreased with increasing $\mathrm{Cu}$ at $\mathrm{pH}$ 5.0, whereas they were not different at $\mathrm{pH} 2.5$.

Samples of HS from this interaction experiment (HS0 and HS100) showed a band at 1700-1720 cm $\mathrm{cm}^{-1}$ that did not appear in the spectrum shown in Figure 1, and which is attributable to the stretching of $-\mathrm{C}=\mathrm{O}-$ of carboxyl and carbonyl groups $[8,9,11,20,32,33]$. This band was less intense at $\mathrm{pH} 5.0$ than at $\mathrm{pH}$ 2.5. Additionally, the intensity of this band decreased with increasing $\mathrm{Cu}$ at both $\mathrm{pHs}$, especially at pH 2.5. Similar results were observed by Álvarez-Puebla et al. [8], who reported the presence of a peak at $1710 \mathrm{~cm}^{-1}$ in humic substances at $\mathrm{pH} 2.0$ whose intensity decreased with higher $\mathrm{pH}$ and greater $\mathrm{Cu}$ concentrations, suggesting that this metal was mainly adsorbed as $\left[\mathrm{Cu}\left(\mathrm{H}_{2} \mathrm{O}\right)_{6}\right]^{2+}$ at low $\mathrm{pH}$, and that the formation of complexes with carboxylic acid is the predominant $\mathrm{Cu}$ adsorption mechanism. Additionally, other works $[9,20,46]$ also observed decreasing signals in this band with the interaction of $\mathrm{Cu}, \mathrm{Cr}$, and $\mathrm{Zn}$ due to their complexation with the carboxyl group. 
On the other hand, the signals of the peaks between 1575 and $1590 \mathrm{~cm}^{-1}$, corresponding to aromatic $\mathrm{C}=\mathrm{C}$ and $\mathrm{C}=\mathrm{O}$ of ketones and carboxyl $[2,11,20,32,33]$, exhibited a greater intensity at $\mathrm{pH} 5.0$ than at $\mathrm{pH}$ 2.5. Boguta et al. [47] reported that this band at low $\mathrm{pH}$ was broadened and shifted due to a possible rearrangement of the coordination between humic acids and the metal ion. Inversely, Zhang et al. [24] reported a decreasing intensity with higher $\mathrm{pH}$ at $1540 \mathrm{~cm}^{-1}$. In this band there were not important differences between $\mathrm{Cu}$ concentrations at either $\mathrm{pH}$. However, Huang et al. [20] observed changes at $1614 \mathrm{~cm}^{-1}$ with the addition of $\mathrm{Cr}(\mathrm{VI})$, although the reaction involved was the reduction of this metal ion, instead of its complexation; other authors $[46,47]$ have also reported increasing intensities at this band with higher $\mathrm{Fe}$ and $\mathrm{Zn}$ concentrations, especially at higher $\mathrm{pH}$ conditions due to the increase of negative charge on humic surfaces and the lower competition with protons [44].

It was also possible to observe a peak at $1400-1470 \mathrm{~cm}^{-1}$, attributable to the -COOantisymmetric stretching of carboxylic acids and the $\mathrm{C}-\mathrm{O}$ stretching and $\mathrm{O}-\mathrm{H}$ deformation of phenolic groups $[2,11,20,32,33]$, that was reduced at $\mathrm{pH} 5.0$ compared to $\mathrm{pH} 2.5$. The intensity of its band also decreased with increasing $\mathrm{Cu}$ concentration, even disappearing in HS100 at pH 5.0, and a shift to higher wavenumbers of the peak $1433 \mathrm{~cm}^{-1}$ in HSO $\left(1429 \mathrm{~cm}^{-1}\right.$ in HS 100 spectrum) at pH 5 was observed, similar to the results obtained by Silvetti et al. [48] who studied the $\mathrm{Cu}$ adsorption capacity of humic acids, suggesting a bidentate chelating mode for $\mathrm{Cu}$ with the carboxylic groups. These results were consistent with those of previous studies $[8,20,46]$, in which this band changed its intensity with the addition of metals $(\mathrm{Cu}, \mathrm{Cr}$, and $\mathrm{Zn})$, providing evidence of interactions between metal ions and carboxylic and phenolic groups. Boguta et al. [44] suggested that $\mathrm{COOH}$ and $\mathrm{OH}$ groups have a strong propensity for $\mathrm{Cu}$ binding, even under acidic $\mathrm{pH}$ conditions, despite the fact that these groups are considered to be dissociated only at high $\mathrm{pH}$.

There was also an appreciable peak at $1210-1220 \mathrm{~cm}^{-1}$, corresponding to the C-O stretching of aryl ethers, the O-H deformation of carboxylic acid, and the C-N- stretching of amide groups [2,11,20,32,33], that was not observed in the spectrum of Figure 1. This band was less intense at $\mathrm{pH} 5.0$ and disappeared with $100 \mathrm{mg} \mathrm{L}^{-1}$ of $\mathrm{Cu}$ (HS100), whereas at $\mathrm{pH} 2.5$ it did not show great variation due to the higher amount of non-dissociated carboxyl groups [46]. Other studies $[8,9,20,46,47]$ also observed a decreasing intensity of this band with higher concentrations of metals $(\mathrm{Cu}, \mathrm{Cr}, \mathrm{Fe}$, and $\mathrm{Zn})$, corroborating the important role of $\mathrm{COOH}$ groups as active centers for metal complexation. In contrast to our results, Boguta and Sokolowska [46] showed that part of the signal of this band did not disappear at pH 5.0, suggesting that not all carboxylic groups are involved in metal binding, probably due to steric effects.

In addition, the spectra showed a band at around $1040 \mathrm{~cm}^{-1}$, attributable to the stretching of -C-Oin aromatic and aryl ethers, alcohols, and polysaccharides [2,3,11,32,33], that was considerably higher at $\mathrm{pH} 5.0$ than at $\mathrm{pH}$ 2.5. Comparing the treatments with different $\mathrm{Cu}$ concentrations, the intensity of this band decreased with increasing $\mathrm{Cu}$ at $\mathrm{pH} 5.0$, whereas at $\mathrm{pH} 2.5$, there were no appreciable changes. Similar results were obtained by previous works [46,47], which observed changes in this band with increasing metal ( $\mathrm{Zn}$ and $\mathrm{Fe}$ ) concentrations which are probably associated with complexation by alcoholic/polysaccharide $\mathrm{CO}$ and $\mathrm{OH}$ groups.

Another noticeable change in the spectra of HS was an increase with higher $\mathrm{pH}$ but a decrease with higher $\mathrm{Cu}$ in the band around $910 \mathrm{~cm}^{-1}$, which belongs to aromatic $\mathrm{C}-\mathrm{H}$, and in the band around $569 \mathrm{~cm}^{-1}$, attributed to aromatic ring bending [32,33].

The FT-IR spectra of sheep and horse manure compost (M) are shown in Figure 8. The interactions of $\mathrm{Cu}$ with the functional groups of this amendment and the effect of $\mathrm{pH}$ were weaker than those in HS, as observed in the ${ }^{13} \mathrm{C}$ NMR analysis. Nevertheless, a slight increase at $\mathrm{pH} 5.0$ of the band between $3300-3500 \mathrm{~cm}^{-1}$ was observed; this was attributable to vibrations of $\mathrm{O}-\mathrm{H}$ bonds in alcohols, phenols, and carboxyl. This increase at higher $\mathrm{pH}$ could be due to the presence of hydroxides of $\mathrm{Cu}$ or other metals that could have caused the peaks shown in this band [8], as explained. Additionally, at $\mathrm{pH} 5.0$, there was a lower intensity at $760-800 \mathrm{~cm}^{-1}$, corresponding to aromatic compounds, whereas at this $\mathrm{pH}$, signals at $569-576 \mathrm{~cm}^{-1}$ were higher than at $\mathrm{pH} 2.5$, as with HS. However, the addition of $\mathrm{Cu}$ did not markedly affect the intensity of these bands. 


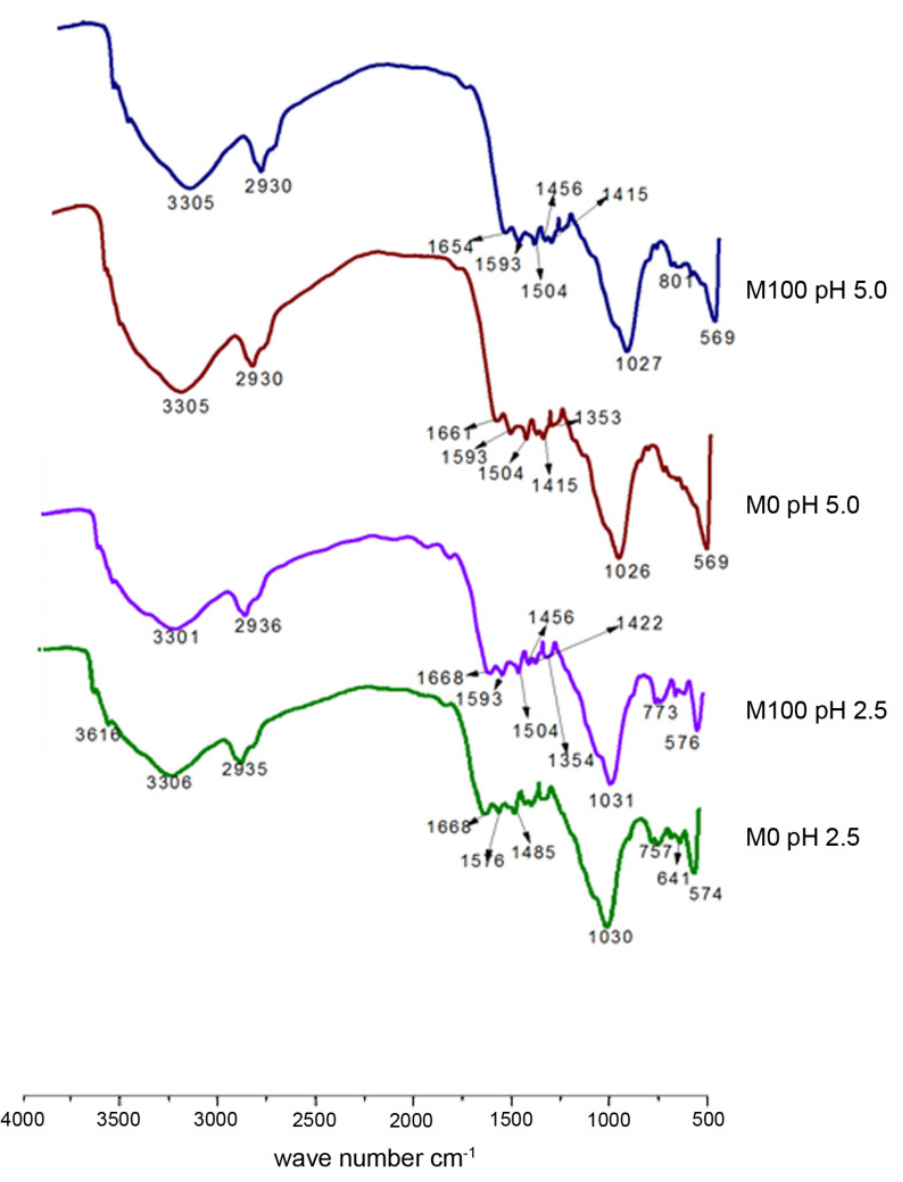

Figure 8. FT-IR spectra of sheep and horse manure compost with the addition of $0 \mathrm{mg} \mathrm{L}^{-1}$ of $\mathrm{Cu}(\mathrm{M} 0)$ and $100 \mathrm{mg} \mathrm{L}^{-1}$ of $\mathrm{Cu}$ (M100), adjusted to $\mathrm{pH} 2.5$ and $\mathrm{pH} 5.0$.

The results obtained from ${ }^{13} \mathrm{C}$ NMR and FT-IR analyses indicated the higher interaction of $\mathrm{Cu}$ with the functional groups of HS than those of M, with the phenolic and especially the carboxyl being the groups which were most responsible for $\mathrm{Cu}$ complexation. This interaction was greater under relatively high $\mathrm{pH}$ conditions ( $\mathrm{pH}$ 5.0).

\section{Conclusions}

Commercial humic substances were the organic amendment with the greatest capacity for $\mathrm{Cu}$ complexation among the studied organic amendments due to their high phenolic and carboxylic functional group contents, providing a good means by which to retain $\mathrm{Cu}$ in contaminated environments. Additionally, this amendment was the most thermostable due to its highly recalcitrant organic matter, with a great ability to retain metals for longer periods of time. Spectroscopic analyses, such as solid-state ${ }^{13} \mathrm{C}$ NMR and FT-IR, resulted in the identification of the complexation sites at which $\mathrm{Cu}$ was bounded to organic matter, showing localized changes in the spectra under different conditions. The $\mathrm{pH}$ was the key factor that affected the chemical structure of the humic substances, to even a greater extent than $\mathrm{Cu}$ concentration, enhancing the interaction between the metal and the organic amendments under high $\mathrm{pH}$ conditions.

Our results suggest that commercial humic substances derived from leonardite could be a useful amendment for the remediation of metals in contaminated agricultural soils due to its high capacity for metal complexation, especially under slightly acidic $\mathrm{pH}$ conditions $(\mathrm{pH} \geq 5)$, and to the great stability of its organic matter and the ability to avoid releasing retained metals over long periods of time. 
Supplementary Materials: The following are available online at http://www.mdpi.com/2073-4395/9/11/762/s1, Figure S1: Solid-state ${ }^{13} \mathrm{C}$ CPMAS NMR spectra of the organic amendments. Figure S2: Solid-state ${ }^{13} \mathrm{C} C P M A S$ NMR spectra of the humic substances with the addition of $0 \mathrm{mg} \mathrm{L}^{-1}$ of $\mathrm{Cu}$ (HSO) and $100 \mathrm{mg} \mathrm{L}^{-1}$ of Cu (HS100), adjusted to $\mathrm{pH} 2.5$ and $\mathrm{pH}$ 5.0. Figure S3: Solid-state ${ }^{13} \mathrm{C}$ CPMAS NMR spectra of the sheep and horse manure compost with the addition of $0 \mathrm{mg} \mathrm{L}^{-1}$ of $\mathrm{Cu}(\mathrm{M} 0)$ and $100 \mathrm{mg} \mathrm{L}^{-1}$ of $\mathrm{Cu}(\mathrm{M} 100)$, adjusted to $\mathrm{pH} 2.5$ and $\mathrm{pH} 5.0$.

Author Contributions: Conceptualization, B.M., C.E. and J.P.-E.; methodology, B.M., C.E. and J.P.-E.; validation, B.M., C.E. and J.P.-E.; investigation, B.M. and J.P.-E.; resources, C.E., E.E. and A.M.; writing-original draft preparation, B.M., C.E. and J.P.-E.; writing-review and editing, C.E., J.P.-E., E.E. and A.M.; supervision, C.E. and E.E.; funding acquisition, C.E., E.E. and A.M.

Funding: This research was funded by MINISTERIO DE ECONOMÍA Y COMPETITIVIDAD (SPAIN), grant number CTM2013-47874-C2-1-R and by MINISTERIO DE CIENCIA, INNOVACIÓN Y UNIVERSIDADES, grant number AGL2016-78490-R.

Acknowledgments: The authors are grateful to Tradecorp ${ }^{\circledR}$, as well as to the 'Migas Calientes' and the Donhierro composting plants for the materials and information on their organic products provided.

Conflicts of Interest: The authors declare no conflict of interest.

\section{References}

1. Senesi, G.S.; Baldassarre, G.; Senesi, N.; Radina, B. Trace element inputs into soils by anthropogenic activities and implications for human health. Chemosphere 1999, 39, 343-377. [CrossRef]

2. Soler-Rovira, P.; Madejón, E.; Madejón, P.; Plaza, C. In situ remediation of metal-contaminated soils with organic amendments: role of humic acids in copper bioavailability. Chemosphere 2010, 79, 844-849. [CrossRef]

3. Tapia, Y.; Cala, V.; Eymar, E.; Frutos, I.; Gárate, A.; Masaguer, A. Chemical characterization and evaluation of composts as organic amendments for immobilizing cadmium. Bioresour. Technol. 2010, 101, 5437-5443. [CrossRef]

4. Kabata-Pendias, A. Trace Elements in Soils and Plants, 4th ed.; CRC Press: Boca Raton, FL, USA, 2011.

5. Clemente, R.; Escolar, A.; Bernal, P. Heavy metals fractionation and organic matter mineralisation in contaminated calcareous soil amended with organic materials. Bioresour. Technol. 2006, 97, 1894-1901. [CrossRef]

6. Kumpiene, J.; Lagerkvist, A.; Maurice, C. Stabilization of $\mathrm{As}, \mathrm{Cr}, \mathrm{Cu}, \mathrm{Pb}$ and $\mathrm{Zn}$ in soil using amendments -A review. Waste Manag. 2008, 28, 215-225. [CrossRef]

7. Senesi, N. Metal-humic substance complexes in the environment. Molecular and mechanistic aspects by multiple spectroscopic approach. In Biogeochemistry of Trace Metals; Adriano, D.C., Ed.; Lewis Publishers: Boca Raton, FL, USA, 1992; pp. 429-451.

8. Álvarez-Puebla, R.A.; Valenzuela-Calahorro, C.; Garrido, J.J. Cu (II) retention on a humic substance. J. Colloid Interf. Sci. 2004, 270, 47-55. [CrossRef]

9. Prado, A.G.S.; Torres, J.D.; Martins, P.C.; Pertusatti, J.; Bolzon, L.B.; Faria, E.A. Studies on copper (II)-and zinc(II)-mixed ligand complexes of humic acid. J. Hazard. Mater. 2006, 136, 585-588. [CrossRef]

10. Tipping, E. Cation Binding by Humic Substances; Cambridge University Press: Cambridge, UK, 2002.

11. Provenzano, M.R.; Senesi, N. Thermal properties of standard and reference humic substances by differential scanning calorimetry. J. Therm. Anal. Calorim. 1999, 57, 517-526. [CrossRef]

12. Provenzano, M.R.; Senesi, N.; Miikki, V. Characterization of composts and humic acids from pulp and paper mill biosludges by DSC in association with FT-IR spectroscopy. J. Therm. Anal. Calorim. 1998, 52, 1037-1046. [CrossRef]

13. Provenzano, M.R.; Senesi, N.; Piccone, G. Thermal and spectroscopic characterization of composts from municipal solid wastes. Compos. Sci. Util. 1998, 6, 67-73. [CrossRef]

14. Provenzano, M.R.; Ouatmane, A.; Hafidi, M.; Senesi, N. Differential scanning calorimetric analysis of composted materials from different sources. J. Therm. Anal. Calorim. 2000, 61, 607-614. [CrossRef]

15. De Oliveira, S.C.; Provenzano, M.R.; Santiago Silva, M.R.; Senesi, N. Maturity Degree of Composts from Municipal Solid Wastes Evaluated by Differential Scanning Calorimetry. Environ. Technol. 2002, 23, 1099-1105. [CrossRef] [PubMed]

16. Pérez-Cruzado, C.; Sande, B.; Ormil, B.; Rovira, P.; Martin-Pastor, M.; Barros, N.; Salgado, J.; Merino, A. Organic matter properties in soils afforested with Pinus radiata. Plant. Soil 2014, 374, 381-398. [CrossRef] 
17. Senesi, N.; Miano, T.M.; Brunetti, G. Humic-like substances in organic amendments and effects on native soil humic substances. In Humic Substances in Terrestrial Ecosystems; Piccolo, A., Ed.; Elsevier: New York, NY, USA, 1996; pp. 531-593.

18. Cardoza, L.A.; Korir, A.K.; Otto, W.H.; Wurrey, C.J.; Larive, C.K. Applications of NMR spectroscopy in environmental science. Prog. Nucl. Magn. Reson. Spectrosc. 2004, 45, 209-238. [CrossRef]

19. Lambert, J.; Lankes, U. Application of nuclear magnetic resonance spectroscopy to structural investigations of refractory organic substances-Principles and definitions. In Refractory Organic Substances in the Environment; Frimmel, F.H., Abbt-Braun, G., Heumann, K.G., Hock, B., Lüdemann, H.-D., Spiteller, M., Eds.; Wiley-VCH: Weinheim, Germany, 2002; pp. 89-95.

20. Huang, S.W.; Chiang, P.N.; Liu, J.C.; Hung, J.T.; Kuane, W.H.; Tzou, Y.M.; Wang, S.L.; Huang, J.H.; Chen, C.C.; Wang, M.K.; et al. Chromate reduction on humic acid derived from a peat soil-Exploration of the activated sites on HAs for chromate removal. Chemosphere 2012, 87, 587-594. [CrossRef]

21. Barančíková, G.; Senesi, N.; Brunetti, G. Chemical and spectroscopic characterization of humic acids isolated from different Slovak soil types. Geoderma 1997, 78, 251-266. [CrossRef]

22. Kwiatkowska, J.; Provenzano, M.R.; Senesi, N. Long term effects of a brown coal-based amendment on the properties of soil humic acids. Geoderma 2008, 148, 200-205. [CrossRef]

23. Bernal, M.P.; Alburquerque, J.A.; Moral, R. Composting of animal manures and chemical criteria for compost maturity assessment. A review. Bioresour. Technol. 2009, 100, 5444-5453. [CrossRef]

24. Zhang, J.; Chen, L.; Yin, H.; Jin, S.; Liu, F.; Chen, H. Mechanism study of humic acid functional groups for Cr (VI) retention: two-dimensional FTIR and ${ }^{13} \mathrm{C} \mathrm{CP} / \mathrm{MAS}$ NMR correlation spectroscopic analysis. Environ. Pollut. 2017, 225, 86-92. [CrossRef]

25. Li, C.; Ji, F.; Wang, S.; Zhang, J.; Gao, Q.; Wu, J.; Zhao, L.; Wang, L.; Zheng, L. Adsorption of Cu (II) on humic acids derived from different organic materials. J. Integr. Agric. 2015, 14, 168-177. [CrossRef]

26. Plante, A.F.; Fernández, J.M.; Leifeld, J. Application of thermal analysis techniques in soil science. Geoderma 2009, 153, 1-10. [CrossRef]

27. Gonet, S.S.; Cieslewicz, J. Differential thermal analysis of sedimentary humic acids in the light of their origin. Environ. Int. 1998, 24, 629-636. [CrossRef]

28. Murphy, E.M.; Zachara, J.M.; Smith, S.C. Influence of mineral-bound humic substances on the sorption of hydrophobic organic compounds. Environ. Sci. Technol. 1990, 24, 1507-1516. [CrossRef]

29. Spaccini, R.; Piccolo, A. Spectroscopic characterization of compost at different maturity stages. Clean Soil Air Water 2008, 36, 152-157. [CrossRef]

30. Chefetz, B.; Hatcher, P.G.; Hadar, Y.; Chen, Y. Chemical and biological characterization of organic matter during composting of municipal solid waste. J. Environ. Qual. 1996, 25, 776-785. [CrossRef]

31. Al-Faiyz, Y.S.S. CPMAS ${ }^{13} \mathrm{C}$ NMR characterization of humic acids from composted agricultural Saudi waste. Arab. J. Chem. 2017, 10, S839-S853. [CrossRef]

32. Gerasimowicz, W.V.; Byler, D.M. Carbon-13 CPMAS NMR and FTIR spectroscopic-studies of humic acids. Soil Sci. 1985, 139, 270-278. [CrossRef]

33. Senesi, N.; Miano, T.M.; Provenzano, M.R.; Brunetti, G. Spectroscopic and compositional comparative characterization of IHSS reference and standard fulvic and humic acids of various origin. Sci. Total Environ. 1989, 81, 143-156. [CrossRef]

34. Sh, T.; Liu, C.Q.; Wang, L. Antimony coordination to humic acid: Nuclear magnetic resonance and X-ray absorption fine structure spectroscopy study. Microchem. J. 2012, 103, 68-73. [CrossRef]

35. Leenheer, J.A.; Brown, G.K.; MacCarthy, P.; Cabaniss, S.E. Models of metal binding structures in fulvic acid from the Suwannee River, Georgia. Environ. Sci. Technol. 1998, 32, 2410-2416. [CrossRef]

36. Preston, C.M.; Dudley, R.L.; Fyfe, C.A.; Mathur, S.P. Effects of variations in contact times and copper contents in a ${ }^{13}$ C CPMAS NMR study of samples of four organic soils. Geoderma 1984, 33, 245-253. [CrossRef]

37. Preston, C.M.; Schnitzer, M.; Ripmeester, J.A. A spectroscopic and chemical investigation on the de-ashing of a humin. Soil Sci. Soc. Am. J. 1989, 53, 1442-1447. [CrossRef]

38. Schilling, M.; Cooper, W.T. Identification of copper binding sites in soil organic matter through chemical modifications and ${ }^{13}$ C CP-MAS NMR spectroscopy. Environ. Sci. Technol. 2004, 38, 5059-5063. [CrossRef] [PubMed]

39. Jerzykiewicz, M. Formation of new radicals in humic acids upon interaction Pb (II) ions. Geoderma 2004, 122, 305-309. [CrossRef] 
40. Smernik, R.J.; Oades, J.M. Effects of added paramagnetic ions on the ${ }^{13} \mathrm{C} \mathrm{CP} / \mathrm{MAS}$ NMR spectrum of a de-ashed soil. Geoderma 1999, 89, 219-248. [CrossRef]

41. Smernik, R.J.; Oades, J.M. Paramagnetic effects on solid state carbon-13 nuclear magnetic resonance spectra of soil organic matter. J. Environ. Qual. 2002, 31, 414-420. [CrossRef]

42. Pfeffer, P.E.; Gerasimowicz, W.V.; Piotrowski, E.G. Effect of paramagnetic iron on quantitation in carbon-13 cross polarization magic angle spinning nuclear magnetic resonance spectrometry of heterogeneous environmental matrixes. Anal. Chem. 1984, 56, 734-741. [CrossRef]

43. Preston, C.M.; Schnitzer, M. ${ }^{13}$ C NMR of humic substances: pH and solvent effects. J. Soil Sci. 1987, 38, 667-678. [CrossRef]

44. Boguta, P.; D’Orazio, V.; Sokołowska, Z.; Senesi, N. Effects of selected chemical and physicochemical properties of humic acids from peat soils on their interaction mechanisms with copper ions at various $\mathrm{pHs}$. J. Geochem. Explor. 2016, 168, 119-126. [CrossRef]

45. Milne, C.J.; Kinniburgh, D.G.; Van Riemsdijk, W.H.; Tipping, E. Generic NICA-Donnan model parameters for metal-ion binding by humic substances. Environ. Sci. Technol. 2003, 37, 958-971. [CrossRef]

46. Boguta, P.; Sokołowska, Z. Interactions of Zn (II) ions with humic acids isolated from various type of soils. Effect of $\mathrm{pH}, \mathrm{Zn}$ concentrations and humic acids chemical properties. PLoS ONE 2016, 11, e0153626. [CrossRef] [PubMed]

47. Boguta, P.; D'Orazio, V.; Senesi, N.; Sokołowska, Z.; Szewczuk-Karpisz, K. Insight into the interaction mechanism of iron ions with soil humic acids. The effect of the $\mathrm{pH}$ and chemical properties of humic acids. J. Environ. Manage. 2019, 245, 367-374. [CrossRef] [PubMed]

48. Silvetti, M.; Demurtas, D.; Garau, G.; Deiana, S.; Castaldi, P. Sorption of Pb, Cu, Cd, and Zn by municipal solid waste composts: metal retention and desorption mechanisms. Clean Soil Air Water 2017, 45, 1600253. [CrossRef]

(C) 2019 by the authors. Licensee MDPI, Basel, Switzerland. This article is an open access article distributed under the terms and conditions of the Creative Commons Attribution (CC BY) license (http://creativecommons.org/licenses/by/4.0/). 